\title{
Water Saving Irrigation in Rice Cultivation with Particular Reference to Alternate Wetting and Drying Method: An Overview
}

\author{
M. M. Husain ${ }^{1 *}$, M. Shahe. Alam², M. H. Kabir ${ }^{1}$, A. K. Khan ${ }^{3}$ and M. M. Islam ${ }^{4}$ \\ ${ }^{1}$ Applied Research Division, ${ }^{2}$ Agril. Economics, ${ }^{3}$ Irrigation Water Management and ${ }^{4}$ Soil Science Division, \\ Bangladesh Rice Research Institute, Gazipur-1701, Bangladesh \\ *Corresponding author and Email: ardbrri@dhaka.net
}

\begin{abstract}
In the context of global energy crisis and water scarcity, rice production system is undergoing changes with the strategy to produce more rice with lesser amount of water. Water saving technology has therefore, been developed and increasingly adopted to irrigate rice in different countries. Impact of alternate wetting and drying (AWD) irrigation as a water saving technique on rice yield, water productivity and environment has been overviewed in this paper. On-farm trials were conducted during the years 2007 and 2008 to validate the adaptability of AWD method of irrigation in Boro rice-variety BRRI dhan29. The trials were conducted at different locations of Gazipur, in which three farmers' plots of rice were irrigated following AWD method, which were then compared with another 3 farmers' plots of rice irrigated in conventional method maintaining 3-5 inches of standing water throughout. The trials have revealed that AWD method saved about $365 \mathrm{~mm}$ irrigation water (about $27 \%$ ) over the conventional irrigation practice. However, there was no adverse effect of AWDirrigation on grain yields of rice. AWD method as perceived by farmers, although reduced irrigation cost, resulted in more weed infestation and was associated with more weeding cost. Following the impressive results of the validation trials, the demonstrations were conducted in the farmers' fields of different districts during boro 2009. In general, the demonstrations were successful to impress the farmers about AWD-irrigation as a water saving and low-cost irrigation method. However assurance of timely availability of irrigation is a precondition for farmers to adopt the technique and weed management using appropriate herbicides is necessary for adoption of the technology.
\end{abstract}

Keywords: Water saving irrigation, alternate wetting and drying, rice yield.

\section{Introduction}

Water for agriculture is becoming increasingly scarce (Rijsberman, 2006). Per capita availability of water resources in Asia is expected to decline by $15-54 \%$ in 2025 compared with 1990 levels (Guerra et al., 1998). In the context of global energy crisis and water scarcity, rice production system is undergoing changes. China will reduce her agricultural water use by $60 \%$ from now on to 2020 . The strategy is to increase productivity at a reduced cost of production so that farming becomes profitable. Another concern is of ecological safety, which is potentially threatened by excess use of natural resources like water for rice cultivation.

In Asia, about $40 \%$ of the fresh water is diverted to irrigate rice land. About $75 \%$ of the global rice production comes from irrigated lands, which are predominantly found in Asia (Sakthivadivel et al., 2001). It has been estimated that 3000- 5000 liters of water is required to produce $1.0 \mathrm{~kg}$ of rice (SAIC, 2007). Precision in irrigation is 
therefore, needed to save water. Through out the rice growing countries, farmers are habituated to maintain continuous standing water in rice land, which is associated with increased energy consumption and eventually higher cost of production. In fact, $20-30 \%$ of the rice production cost is incurred for irrigation only in case of irrigated rice depending on soil type and mode of payment (Alam, 2006). Alternative water saving irrigation techniques have been developed and increasingly adopted in rice growing countries during recent decades. The aims of this paper is to overview the adoption and impact of water saving irrigation technology with particular reference to alternate wetting and drying irrigation in rice cultivation. The results of some on-farm validation trials on AWD irrigation in Bangladesh is also discussed.

\section{Water saving irrigation technology- alternate wetting and drying (AWD)}

Water Scientists have developed technology for producing rice with less water. The technique is so-called "Alternate Wet and Dry" (AWD) method of irrigation in which irrigation water is applied to obtain flooded conditions after a certain number of days have elapsed after the disappearance of ponded water (Bouman et al., 2007). The AWD technique considers rice crop like any other irrigated crop, with no standing water and maintaining an aerobic condition in the soil. The main principle underlying the technique is to increase yield per unit transpiration, reducing non-beneficial depletions, effective use of rainfall and reducing outflow.

The AWD method of irrigation is actually the application of irrigation water based on visual observation of water table in the rice land. The concept is that irrigation is applied in rice land to bring ponding conditions after a certain period has elapsed after the ponded water has receded from the field. (Sakthivadivel et al., 2001, Bouman et al., 2007). The period of non-flooded condition may very depending on soil texture, but normally that could be 3-4 days. AWD irrigation begins from 10-15 days after transplanting or 20 days after direct seeding of rice seeds. Irrigation is applied with a depth of about 5-cm after the water level reaches 15-20 $\mathrm{cm}$ depth below the ground surface. At this condition, there is enough water for the rice plants to maintain photosynthesis, even though water is not seen on the top. Around flowering, one week before to one week after the peak of flowering, ponded water should be kept at $5-\mathrm{cm}$ depth. After that, during grain filling and ripening, AWD can be applied again. However, no further irrigation is needed at the onset of hard dough stage.

The practical way to implement AWD is to monitor the water depth in the field using a "field water tube" - preferably a perforated PCV pipe installed in the rice field to allow observation of water level. The pipe is installed in a spot that represents the whole field (neither at depression nor at an elevated patch). The PVC pipe of 10$\mathrm{cm}$ diameter and about $30-\mathrm{cm}$ long be installed such that the top 10-cm (non perforated) remains above the ground and the rest $20-\mathrm{cm}$ (perforated) is placed below the ground surface. The AWD irrigation has been widely adopted in China. This technique was promoted among farmers and has become a common practice in Japan and Sri Lanka and being tested by farmers in India and Philippines. Recently, the technique has been introduced in Bangladesh.

\section{Grain yield and water productivity under different water saving irrigations}

\subsection{Grain yield}

Many studies have revealed that continuous submergence is not essential for obtaining high yield of rice (Guerra et al., 1998). Tabbal et al. (1992) and Singh et al. (1996) reported that maintaining a very thin layer, at saturated soil conditions or at alternate wetting and drying can reduce water applied to rice field by about 40$70 \%$ compared to continuous shallow submergence, without significant yield loss. In 31 field experiments analyzed by Bouman and Tuong, (2001), 92\% of the AWD treatments resulted in yield reduction varying from just more than 0 to $70 \%$ compared with those of the flooded controls. 
In Philippines, grain yields of rice did not vary greatly with 4-8-day intervals between irrigation. However, grain yield dropped $1.0 \mathrm{t} / \mathrm{ha}$, or more with irrigation intervals beyond 8 days (De Dalta et al., 1973). Qinghua et al. (2002) reported that intermittent irrigation reduced rice yield by $4-6 \%$ than the flooded treatment. Water saving in alternately submerged and non-submerged irrigation was $13-16 \%$ compared with continuously submerged regime (Belder et al., 2002), while water regime did not significantly influence yield.

\subsection{Water productivity}

The concept of increasing water productivity "more crop per drop" was first introduced at the International Water Management Institute (IWMI), Sri Lanka in the mid-1990s (Giordano et al., 2006). Water productivity denotes the amount or volume of product (rice yield) per unit of water used). Castaneda et al. (2002) found that under aerobic rice cultivation in China, water productivity was increased by $20-40 \%$ over that under flooded conditions, because water use deceased relatively more than yield. Intermittent irrigation required $27-37 \%$ less water than the flooded treatments whereas grain yield increased by 4 to $6 \%$.

Sakthivadivel et al. (2001) reviewed the effects of water saving techniques of irrigation (WSI) on rice yield and water productivity in many countries. Studies in International Rice Research Institute (IRRI) revealed that rice yield generally declined as soon as the field water content reached or dropped below saturation. Yield reduction was reported to be upto $10 \%$ when the soil water was kept at satuation. Water productivity in on-farm studies varied from 0.1$1.9 \mathrm{~g}$ grains per $\mathrm{Kg}$ of water depending on rice varieties and environment. It was revealed that water saving irrigation techniques could substantially reduce water input at the field level and generally increased water productivity of irrigation. WSI maintained or decreased land productivity compared with continuous flooded rice and then did not result in increased total rice production with less water.
In Japan, alternate wetting and drying irrigation was promoted among farmers in late 1950s and the technique has become very popular. Investigations conducted by Anbumozhi et al. (1998) on the effects of continuous, intermittent and variable ponding and also under different doses of fertilizer application on rice have shown that at $9 \mathrm{~cm}$ ponding depth, grain yield of 5.2 and $4.95 \mathrm{t} / \mathrm{ha}$ were obtained with continuous and intermittent ponding, respectively. AWD irrigation resulted in higher water productivity of $1.26 \mathrm{~kg} / \mathrm{m}^{3}$ compared to continuous flooding $\left(0.96 \mathrm{~kg} / \mathrm{m}^{3}\right)$. Studies conducted in China during the 1980-1990s showed water saving irrigation following alternate flooding and drying consistently produced higher yields than the traditional practice of continuous flooding. Studies in India also revealed increased yield of rice irrigated following AWD irrigation. However, the response to AWD irrigation varied depending on rice varieties, soil type and seasons. In Bangladesh, large number of on-farm trials have revealed that AWD method of irrigation in boro rice using perforated PVC pipe produced grain yield of $5.8 \mathrm{t} / \mathrm{ha}$, which was about $8 \%$ higher than that produced by farmers' practice of continuous ponding water in rice land (Sattar et al., 2009). Water productivity in those trails was about $30 \%$ heigher under AWD compared with farmers' practice of continuous standing water.

\subsection{Irrigated rice and weed growth}

Emergence of weeds and the types of weeds in a weed population are closely related to the moisture content of the soil and the water depth in the rice field. Moist, but un-flooded soil, warm temperatures and adequate light favour the growth of grass. Five $\mathrm{cm}$ of continuous standing water may substantially control grasses. But infestation of other weeds very greatly with the depth of standing water, with sedges being severe under dry condition (De Datta, 1981). Permanently flooded rice land tends to have less weed growth than rice land that is not permanently flooded (Mortimer and Hill, 1999). 


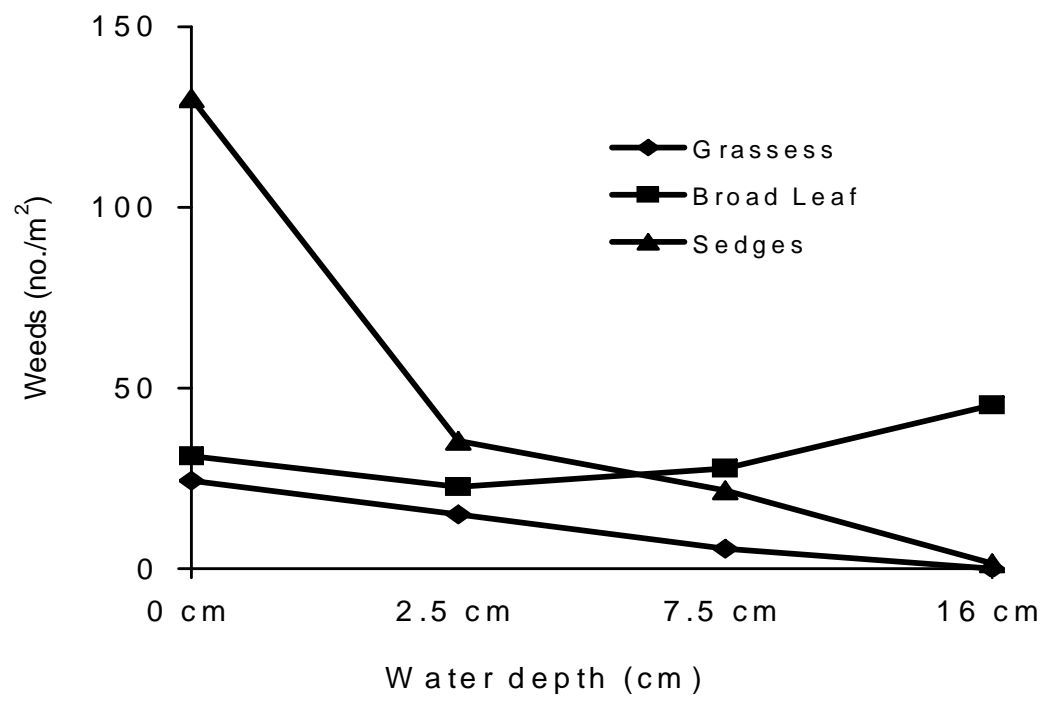

Fig. 1. Weed population as influenced by water depth in the rice land (Adopted from De Datta, 1981).

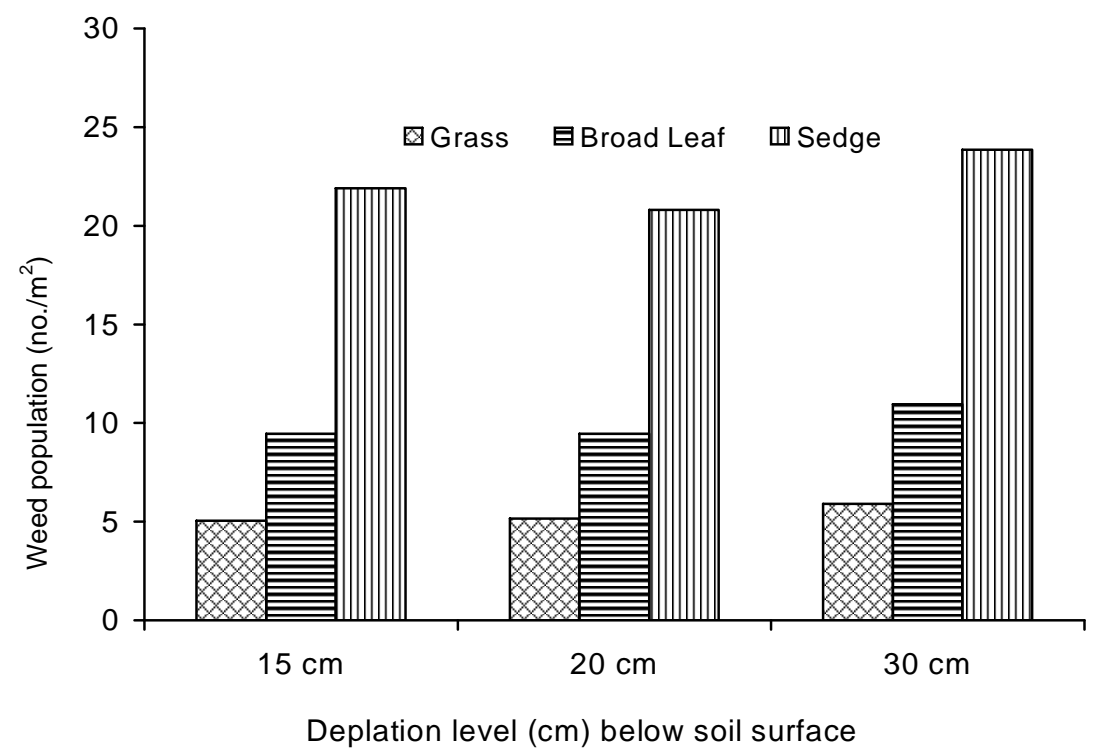

Fig. 2. Weed infestations under various water depletion levels (Khan, 2009 unpublished data). 
Weed infestation and types of weed population are closely related with water content of the soil and water depth in the rice land. Grasses can substantially be controlled by continuous flooding. Infestation of weeds may vary greatly with depth of standing water (Fig. 1 and 2).

Under dry condition, sedge population is the maximum. Studies show that with the depletion of water level below $15 \mathrm{~cm}$ and further, grass population is always higher in the boro rice land (Fig. 2).

\subsection{Irrigated rice and its environmental impacts}

Flooding of rice land increases the availability of phosphorous, potassium, calcium etc. But flooding of highly permeable soils causes leaching down of nutrients from the root zone (De Datta, 1981). Drainage with moderate drying allows oxygen to penetrate into the soil. Percolating water can bring oxygen into the soils and leach toxic substance beyond the rooting zone. Generally, most rice varieties maintain better growth and produce higher grain yields when grown in a flooded soil than when grown in a non-flooded soil.

Flooded rice land is associated with emission of several greenhouse gases. Experiments conducted in China showed that there was pronounced effect of altered water management on greenhouse gas emission. Flooding of the soil is responsible for sustained emission of methane. Mid-season drainage greatly reduces methane emission. $\mathrm{CH}_{4}$ emission from ground covered rice productions systems was low compared with conventional flooded rice (Dittert et al., 2002). Maintenance of standing water throughout rice crop growth may potentially promote methane emission, particularly in the soils rich in organic carbon. It was estimated that low land rice emitted about 10-20\% of global methane in early 1980s (Kirk, 2004). Estimates of annual methane emissions from rice land are in the range of $5-10 \%$ of the total global emission
(Kirk, 2004). Amonia volatilization from urea fertilizer is the major pathway of $\mathrm{N}$ loss in tropical flooded rice land (Buresh and De Datta, 1990). Irrigated rice system is a significant sink for atmospheric $\mathrm{CO}_{2}$, a significant source of methane $\left(\mathrm{CH}_{4}\right)$ and also a small source of nitrous oxide $\left(\mathrm{N}_{2} \mathrm{O}\right)$ (Bouman et al., 2007.

Excess withdrawal of underground water to irrigate rice can also be potentially associated with arsenic contamination in the rice plants and may endanger human and animal health (Anonymous, 2004-05). Thus, the growing concept of "Evergreen Revolution" - "increasing crop productivity is perpetuity without associated ecological harm" (Swaminathan, 2008) may be hindered. However, the risk of Ascontaminated irrigation water to crop production has received little attention until now. Duxbury and Zavala (2005) estimated that ten years of irrigating paddy fields with As-contaminated water would add $5-10 \mathrm{mg} / \mathrm{kg}$ soil to $41 \%$ of the 456 study sites included in their study. Williams et al. (2006) in an extensive sampling of rice throughout Bangladesh found a positive correlation between As in the ground water and As in the rice. AWD irrigation practices also provide opportunities to improve human health. The intermittent drying of rice land produced dramatic impact on the control of mosquito populations associated with the propagation of vector-borne diseases in Portugal and Indonesia as reported by Sakthivadivel et al. (2001).

\section{AWD irrigation in Bangladesh}

BRRI Adaptive Research division validated the technology in farmers' fields of Gazipur during boro season of 2007 and 2008. Being highly encouraged by the on-farm performance of the AWD irrigation, the technology was demonstrated in ten locations of the country during boro season, 2009. Outcomes of those activities are presented below.

The validation trials were undertaken during Boro, 2007 and 2008 season at Kapasia, Gazipur. Six dispersed farmers' plots of equal sizes (about 33 
dec.) were selected in each year at almost equal distance from the irrigation pump within the same command area. Out of the six plots, 3 were irrigated following the alternate wetting and drying (i.e. irrigate the plots 3 days after pounded water disappeared from the field) and the rest 3 plots were irrigated following conventional farmers' practices (i.e. continuous standing water throughout the growing period) and were considered as 3 replications. The rice variety was BRRI dhan29 and was cultivated under farmers' management. The amount of applied water was measured by a depth gauge in the plot and the time required for each irrigation was also recorded. Rainfall data were collected from the BRRI meteorology station, about $20 \mathrm{~km}$ far from the trial sites. Following the validation trials, the demonstrations were conducted in ten locations of the country during Boro, 2009. In the AWDirrigation plots perforated PVC pipes were installed and monitored. Farmers' perception about the technology was also analyzed.

\section{Results and discussion}

Boro 2007: Table 1 reveals that total irrigation water applied in alternate wetting and drying (AWD) method for the whole growing season was about $730 \mathrm{~mm}$, whereas that under farmer's practice was about $1030 \mathrm{~mm}$ (excluding $176 \mathrm{~mm}$ rainfall) during the growing season. That is, about $300 \mathrm{~mm}$ water was saved in AWD irrigation. The rainfall was distributed during the tillering and reproductive stages, which was congenial for Boro rice production. Time required for irrigation during the crop-growing season for same area under alternate wetting and drying method and farmers' practice were, respectively, 23.25 and $43.60 \mathrm{hrs}$. This indicates that about $29 \%$ irrigation water and about $47 \%$ application time could be saved by alternate wetting and drying method without affecting grain yields (Table 1). Alternate wetting and drying method thus reduced the irrigation cost. Grain yields under both AWD and conventional methods of irrigation were very similar at about $7.2 \mathrm{t} / \mathrm{ha}$, that is AWD method did not affect grain yield.

\section{Farmers' perception}

The farmers perceived that alternate wetting and drying method reduces the number of irrigation without affecting yield. It reduces fuel or electricity cost for pump operation and hence reduces irrigation cost. However, the farmers felt that weed infestation increases under alternate wetting and drying method of irrigation and hence needs more labour for controlling weeds and thus increases weeding cost.

Table 1. Grain yield, water and time saved through alternate wetting and drying method at Farmer's field, Boro, 2007.

\begin{tabular}{|l|c|c|c|c|c|c|c|}
\hline Irrigation methods & $\begin{array}{c}\text { Applied } \\
\text { water } \\
(\mathrm{mm})\end{array}$ & $\begin{array}{c}\text { Rainfall* } \\
(\mathrm{mm})\end{array}$ & $\begin{array}{c}\text { Total } \\
(\mathrm{mm})\end{array}$ & $\begin{array}{c}\text { Irrigation } \\
\text { time (hr.) }\end{array}$ & $\begin{array}{c}\text { Grain } \\
\text { yield } \\
\mathrm{t} / \mathrm{ha})\end{array}$ & $\begin{array}{c}\text { Water } \\
\text { saved over } \\
\text { farmer's } \\
\text { practice } \\
(\%)\end{array}$ & $\begin{array}{c}\text { Time } \\
\text { saved } \\
\text { over } \\
\text { farmer's } \\
\text { practice } \\
(\%)\end{array}$ \\
\hline $\begin{array}{l}\text { Irrigation at 3 } \\
\text { days after ponded } \\
\text { water } \\
\text { disappearance }\end{array}$ & 730 & 176 & 906 & 23.25 & 7.23 & & \\
\hline $\begin{array}{l}\text { Irrigation } \\
\text { following } \\
\text { farmers' practice }\end{array}$ & 1030 & 176 & 1206 & 43.60 & 7.18 & 29 & 47 \\
\hline
\end{tabular}

\footnotetext{
* Rainfall was measured at BRRI Gazipur about $25 \mathrm{Km}$ far from the experimental site.
} 
Boro, 2008: Table 2 reveals that during boro 2008 , total amount of irrigation water applied in alternate wetting and drying plots for the whole growing season was about $820 \mathrm{~mm}$, whereas that under farmer's practice was about $1185 \mathrm{~mm}$. That is, about $365 \mathrm{~mm}$ water was saved in AWD irrigation. Time required for irrigation during the crop-growing season for same area under alternate wetting and drying method and farmers' practice were respectively, 14.35 and 20.65 hrs. This indicates that about $31 \%$ field irrigation water and about $45 \%$ application time could be saved by alternate wetting and drying method without affecting grain yields (Table 2). Therefore, Alternate wetting and drying method could thus save irrigation water and reduce the irrigation cost substantially.

On-farm demonstrations of AWD - irrigation were also conducted by others in Bangladesh Department of Agriculture Extension (DAE) has shown that over 460 locations, AWD- irrigation gave 0.61 ton higher yield per ha over traditional irrigation. AWD - irrigation also saved $28 \%$ of time compared to traditional practice. Similarly, Bangladesh Agricultural Development Corporation (BADC) and Barind Multipurpose Development Authority BMDA) have found slight yield advantages and significant amounts of water savings by AWD- irrigation.

\section{Farmer's perception}

Farmers' perception on AWD method was very similar to that observed during 2007. Farmers perceived that alternate wetting and drying method reduces the number of irrigation without affecting yield. It reduces fuel or electricity cost for pump operation and hence reduces irrigation cost. Increased weed infestation and the associated increased cost of weeding was identified as the main limitation of this technology.

Boro, 2009: Demonstrations were conducted in 10 locations of Gazipur, Netrokona, Shirajgonj, Comilla, Sylhet, Satkhira and Barisal to demonstrate the advantages of AWD-irrigation, using perforated PVC pipe. Generally, AWD method was found to be a good water saving technology as perceived by the farmers.

\section{Socio-economical aspects of AWD irrigation}

In Bangladesh, AWD irrigation has been a recent introduction. Alam et al. (2009) conducted a study on its socio-economic impacts over 87 farmers who adopted the technology. They found that the farmers who adopted the AWD technology required about $30 \%$ less water in growing irrigated rice compared to conventional irrigation. The use of less water in AWD irrigation was associated with 12 to $15 \%$ reduction in cost. A partial budget analysis showed that adoption of AWD irrigation would result in a net profit of about TK. 4200.00 per hectare over the conventional irrigation of continuous standing water.

Table 2. Water and time saved through alternate wetting and drying method at Farmer's field, Boro, 2007-08

\begin{tabular}{|l|c|c|c|c|c|c|c|}
\hline Irrigation methods & $\begin{array}{c}\text { Applied } \\
\text { water } \\
(\mathrm{mm})\end{array}$ & $\begin{array}{c}\text { Rainfall* } \\
(\mathrm{mm})\end{array}$ & $\begin{array}{c}\text { Total } \\
(\mathrm{mm})\end{array}$ & $\begin{array}{c}\text { Irrigat } \\
\text { ion } \\
\text { time } \\
(\mathrm{hr})\end{array}$ & $\begin{array}{c}\text { Grain } \\
\text { yield } \\
(\mathrm{t} / \mathrm{ha})\end{array}$ & $\begin{array}{c}\text { Water saved } \\
\text { over } \\
\text { farmer's } \\
\text { practice (\%) }\end{array}$ & $\begin{array}{c}\text { Time } \\
\text { saved over } \\
\text { farmer's } \\
\text { practice } \\
(\%)\end{array}$ \\
\hline $\begin{array}{l}\text { Irrigation at 3 } \\
\text { days after ponded } \\
\text { water } \\
\text { disappearance }\end{array}$ & 820 & 159 & 979 & 14.35 & 8.52 & & \\
\cline { 1 - 5 } $\begin{array}{l}\text { Irrigation } \\
\text { following } \\
\text { farmers' practice }\end{array}$ & 1185 & 159 & 1344 & 20.65 & 8.42 & 27 & 30.5 \\
\hline
\end{tabular}

* Rainfall of BRRI Gazipur considered as the rainfall of the experimental site. 


\section{Conclusions and Recommendations}

AWD is an appropriate technology in the context of energy crisis, water scarcity and environmental concern. AWD can potentially make rice cultivation profitable via reducing irrigation cost and increasing yield to some extent. However, the farmers perceived that under conditions of Bangladesh, AWD - irrigation is difficult as there is no guarantee of getting water when the land becomes dry. Weed infestations are usually more under AWD- irrigation.

Effective weed management by applying herbicides is, therefore, to be practiced for adoption of AWD- irrigation. Participatory approach is needed for dissemination of the technique. For example, planting time and variety selection should be similar, so that the rice lands can be dried up and re-irrigated at the same time. Pricing of irrigation water needs to be regulated i.e. less cost for less amounts of water being applied should be charged by the pump owners.

\section{References}

Alam, M. Shahe, M. S. Islam, M. A. Salam and M. A. Islam, 2009. Economics of Alternate Wetting and Drying Method of Irrigation: Evidences from farm level study (This Volume).

Alam, M. Shahe. 2006. Factors affecting yield gap and efficiency in rice production in some selected areas of Bangladesh. Ph.D. thesis, Faculty of social sciences (Dept. of Economics). Jahangirnagar University, Savar, Dhaka.

Anboumozhi, V. E. Hamaji, and T. Tabuchi, 1998. Ruce comply and yield as influenced by changes in ponding water depth, water refine and festigation level. Agricultural Water Management, 37, 241-253.

Anonymous, 2004-05. Annual report. Arsenic contaminations on agricultural sustainability and food Quality (Internet).

Bouman, B.A. M., R.M. Lampayan and T.P. Toung. 2007. Water management in irrigated rice: Cropping with water scarcity.
International Rice Research Institute. Los Banos, Philippines.

Belder, P. B., A. M. Bouman, J. H. J. Spiertz, Lu Guoan and E. J. P Quilang. 2002. Water use of continuously submerged and no submerged irrigated low land rice. Proceedings of a thematic workshop on water-wise rice production, 8-11 April, 2002 at IRRI headquarters in Los Banos, Philippines.

Buresh, R. J and De Datta. 1990. Dnitrification losses from puddle soils in the tropics. Biol. Fertil. Soils 9:1-13.

Bouman, B. A. M. and T. P. Toung. 2001. Field Water Management to same water and its productivity in irrigated rice. Agricultural Water Management, 49: 11-30.

Castaneda, A. R., B. A. M. Bouman, S. Peng and R. M Visperus. 2002. The effects of irrigation management on yield and water productivity of inbred, hybrid and aerobic rice varieties. Proceedings of a thematic workshop on water-wise rice production, 811 April, 2002 at IRRI headquarters in Los Banos, Philippines.

De Datta, S. K., H. K. Krupp, E.I. Alvarez and S. C. Modgal. 1973. Water management practices in flooded tropical rice. Pages 118 in International Rice Research Institute. Water Management in Philippines irrigation systems: research and operation, Los Banos, Philippines.

Giordano, M.A. F. R. Rijsberman and R. M. Salith, 2006. More Crop Per Drop: Revisiting a Research Paradigm. IWA Publishing, Alliama House, 12 Coxton Streeet, London, SWIHOQS, UK.

De Datta S. K. 1981. Principles and Practices of rice production. John Wiley and Sons. Inc. pp. 618.

Dittert, K., Lin Shan, C. Kreye, Zheng Xunhua, $\mathrm{Xu}$ Yangchun, Lu Xuejuan, Huang Yao, Shen Qirong, Fan Xiaolin and B. Satte lmacher, 2002. Proceedings of a thematic workshop on water-wise rice production, 8- 
11 April, 2002 at IRRI headquarters in Los Banos, Philippines.

Duxbury J. M. and Zavala Y. J. 2005. What are safe levels of arsenic in food and soils? In: Behavior of arsenic in aquifers, soils and plants (Conference Proceedings), International Symposium, Dhaka, 2005.

Guerra, L. C., Bhuiyan S. I., Tuong T. P. and R Barker, 1998. Producing more rice with less water from irrigated systems. SWIM paper 5. International Irrigation Management Institute, Colombo, Srilanka.

Kick, G. 2004. The biochemistry of submerged soils. Chichester, West Sussex (UK). John Wiley and Sons. p. 291.

Khan, A. K. 2009. Irrigation and Water Management Division, Bangladesh Rice Research Institute, Gazipur-1701 (unpublished data).

Mortimer, A. M, and Hill, J. E. 1999. Weed species shifts in response to broad spetrun herbicides in sub-tropical and tropical crops. Brighton Crop Protection Conference. 2: 425-437.

Qinghua Shi, Xiaochun Muying Li, Xueming Tan, and Fengfeng Xu, 2002. Effect of different water management practices on rice growth. Proceedings of a thematic workshop on water-wise rice production, 811 April, 2002 at IRRI headquarters in Los Banos, Philippines.

Rijsberman, F. R. 2006. Water Scarcity : Fact of fiction. Agricultural Water Management 80:5-22.

Sakthivadivel, R., D. J. Molden, Hilmy Sally Li Yuanhua and Dong Bin. 2001. Water saving irrigation techniques in rice irrigation: A review of AWDI practices. International Commission on Irrigation and Drainage. $1^{\text {st }}$ Asian Regional Conference. Seoul, 2001.

Singh C. B. T. S. Aujla, B. S. Sandhu and K. L. Khera. 1996. Effects of transplanting date and irrigation regime on growth, yield and water use in rice (Oryza Sativa) in northern India. Indian Journal of Agricultural Science, 66: 137-141.

Swaminathan, M. S. 2008. Science and technology: Prime mover of Agrarian prosperity. Paper presented in the "Sciencebased Agricultural Transformation Towards Alleviation of Huger and poverty in SAARC countries. 5 March 2008. New Delhi, India.

Sattar, M. A., M. A. Rashid, M. N. Hassan, H. R. Molla, A. K. Khan, S. Parveen, D.Roy and H. Mahamud. 2009. Alternate Wetting and Drying Technology for Water Saving in Boro Rice Production for the Selected Locations of Bangladesh. Paper presented in of the National Workshop on Adoption and Success of AWD Technology for Rice Production held on 15 July 2009 at the BRRI, Gazipur.

SAIC (SAARC Agriculture Information Centre), 2007. IRRI develops technology for producing irrigated rice with less water. SAIC Newsletter. A Quarterly Publicatiion of SAARC Agriculture Centre. Vol. 17:2. No. 2. PP.4-6.

Tabbal, D. F., R. M. Lampayan and S. I. Bhuiyan, 1992. Water efficient irrigation technique for rice. In: Soil and water engineering for paddy field management (ed.) VVN. Murty and K Koga. Proceedings of the in the international workshop on soil and water engineering for paddy field management, 28-30 Germany/Asian Institute of Technology, Bangkok, Thailand.

Williams P. N., Islam M. R., Adomako E. E., Raab A., Hossain S. A., Zhu Y. G. and Meharg A. A. 2006. Increase in rice grain arsenic for regions of Bangladesh irrigating paddies with elevated arsenic in groundwater. Environmental Science Technology, 40: 4903-4908. 